原著皮膚の二点融合感覚と銊刺激の効果

前山文子* 熊本 賢三 岩瀬 善彦

要旨 目的：皮膚の二点融合距離から融合野を求めた。この融合野は 鍼刺激によってはなはだしく拡大する。この拡大効果を中枢神経機序 の立場から明らかにした。

方法：二点融合距離は触あるいは圧の二点刺激を一点と感ずる最大 の二点間距離で求め, 縦軸と横軸の測定から融合野を作図してその面 積を算出した。

結果及び結論：融合野は触よりも圧覚刺激で面積が小さく再現性も 高い。上肢の二点融合野の形は長方形に近く, 上肢の末梢部ほど面積 が小さくなる。鍼刺激によって融合野は拡大する。これは鍼刺激によ る求心性神経のインパルスによって, 中枢への伝導系内の側方抑制機 構が作動しなくなった結果と考えられる。

\section{I 緒 言}

鍼尒の治療に当って経穴が重要な意味を持って おり，また治療上の特殊性をも有する。

今回この経穴刺激による治療効果の一端を明ら かにするため, 皮虐感覚の分野より実験を行った よく知られている皮膚感覚は触・圧・痛・温・冷 であるが，この感覚点の存在は時間的に変動する ことが多い。これは見掛け上の現象で感覚点の閾 值の変動を反映しているものである。したがって 感覚点の分布や密度の測定から銊炃の効果を判定 することは非常によい着眼点であるが ${ }^{2)}$, 再現性の 点で問題がある。そこで皮膚の感覚点より高次の 感覚内容を持つ二点弁別閾值を改良した二点融合 感覚について，上肢と体幹で実験を行いそれぞれ

* Fumiko MAEYAMA 明治鍼尒大学生理学教室

(現在 金沢市, 東洋医学臨床研究所)

共同研究者 : Kenzo KUMAMOTO 明治銊炎大学解剖学教室, Yoshihiko IwASE 明治銊尒大学生理学教室

Key Words : 二点弁別, 二点融合感覚, 融合野, 受容野, 側方抑制，銊刺激，感覚点，経穴，非経穴
興味ある所見が得られた

この融合距離に基づく二点融合野は，皮膚の受 容野の知見に該当すること，また経穴と非経穴の 鍼刺激による二点融合野の拡大効果とその神経機 序について報告する。

\section{II 実験方法}

（1）二点融合野の測定法

被検者は19２8才までの健康な男女学生で，上 肢での測定は仰臥位，背部では座位で，アイマス ク (eye mask) をかけて安静閉眼状態で行った。 方法は, 触覚ではナイロン系を介して直径 $1.3 \mathrm{~mm}$, 長さ $3 \mathrm{~mm}$ の木片を 2 個つけたノギス（図1 A), 圧覚では直径 $1.0 \mathrm{~mm}$, 長さ $15 \mathrm{~mm}$ の木棒を 2 個つ けたノギスを用いた（図１＇＇）。皮膚への二点の刺 激圧を一定にするために，ノギスを被検者の皮虐 上に平行に当てることが大切で，皮膚の彎曲には 充分注意した。

皮膚への二点の刺激圧を一定にするために，検 者は圧力トランスデューサーにノギスを押しつけ て練習を重ねた。図 1 B，B'がその試行例の一部 で，4回の圧記録を示しほぼ一定の二点刺激圧で 
ある。上肢では通常, 触の刺激閾值は $2 \mathrm{gm}$, 圧の 刺激閾值は $10 \mathrm{gm} の$ 規準で二点刺激を行った。こ れらは被検者または部位により圧の閾值が異なる。 二点刺激を皮䖉に加之る時間は，圧覚では $3 \sim 4$ 秒，触覚では $1 \sim 2$ 秒である。

二点弁別閾值では二点間距離を次第に大きくし て，二点間を離れている点として識別できる最小 の值を求める。これに反して二点融合距離は二点 間距離を次第に狭くしていって二点刺激が融合し て一点と感ずる最大距離で求めた。図 $1 \mathrm{C}, \mathrm{C}^{\prime}$ は, 二点刺激を触覚と圧覚で行ったときの二点融合感 覚を模式的に示している。横軸は二点間の距離, 縦軸は感覚量である。触覚より圧覚では感覚量が 大きいので融合感覚が判定しやすい。二点弁別閾 值の場合には感覚量が小さくなるため正確な測定 が得られにくいことが多い。したがって圧の二点
融合距離では測定結果の再現性が高い。なおここ の二点融合距離の測定では『一点』と答えるのが 一般的であるが，被検者によってはこの時に『棒 一点』と答える者もある。上肢の場合, デルマト 一ムの長軸方向に縦軸を取った。そして縦軸一カ 所, 横軸三力所で二点融合距離の測定を行って, それに囲まれた部分の面積を算出しこれを二点融 合(感覚)野 Two-Point Fused Sensory Area（以 下融合野という）と名づけた。

実験を行う場合の注意点として, 測定部位近く の皮膚上にノギス以外のものが接触していると， 測定誤差や誤認をきたし易かった。例えば検者の 手が被検者の皮虐に近接すると，それが温覚とな り測定に支障をきたす場合がある。そのため検者 の手が皮虐に触れないようにするため検者の前腕 の下に台を置くことで調整した。またこの台を置
触覚刺激

A

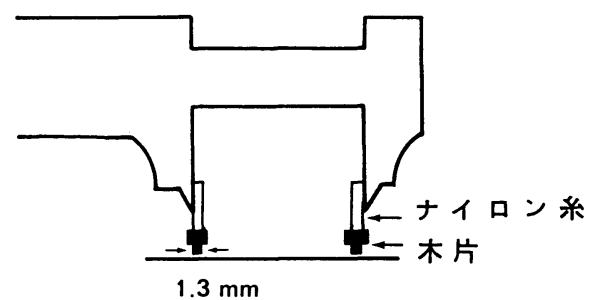

B

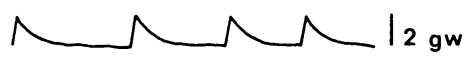

C

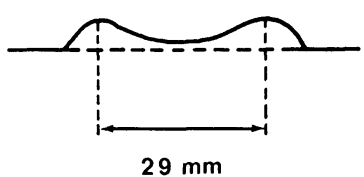

\section{圧覚刺激}

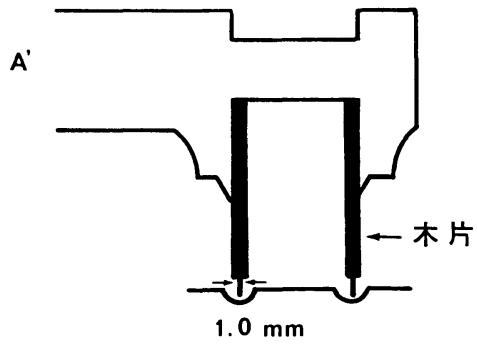

B'

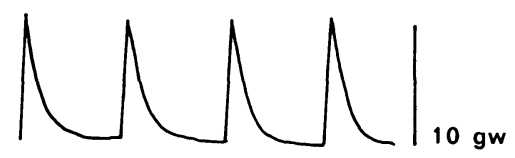

C'

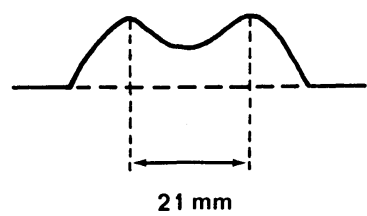

図 1 実験方法

$\mathrm{A}, \mathrm{A}^{\prime}$ : 二点融合距離の測定用ノギス

$\mathrm{B}, \mathrm{B}^{\prime}$ : 圧トランスジューサーでモニター した各ノギスの接触圧

$C, C^{\prime}$ : 二点融合感覚の感覚量 $($ 縦) と二点 融合距離 (横) 
くことにより検者の手は安定し，加える圧を一定 にするためにも効果があった。

その他の実験条件として被検者が実験に慣れる ことが必要である。また実験中, 被検者は話し声, 電話の音, ドアの開閉の音等, 周囲の状況に影響 を受け易い。これらの雑音を取り払うため実験に 際しては充分留意した。室温は $25 \sim 27^{\circ} \mathrm{C}$ を保つよ う注意を払った。また暑い季節や運動などによる 発汗が多い場合には測定値が変わるので，実験前 に10分間の安静状態を取った。次に実験を行う時 間帯を考慮した。すなわち午後は遅ければ遅いほ ど測定值の再現性が悪く，午前中の実験では再現 性が良い。これは被検者が学生のため授業終了後 で疲れていたり，実験終了時間を気にしたりする 心理的条件によるものと思われる。

(2) 圧点の测定法 ${ }^{4,5)}$

上腕外側部，前腕外側部，手背部で測定を行っ た。皮膚表面に $20 \times 20 \mathrm{~mm}$ 内に $2 \mathrm{~mm}$ ごとの碁盤
目（計121点）を捺印し，その内枠の81点について Frey の刺激毛をもってその交点を次々に刺激し た。刺激毛は木棒の先端に直径 $0.288 \mathrm{~mm}$, 長さ 25 $\mathrm{mm}$ のナイロン製の系をつけたものである。そし て皮膚がたわむ程度の圧（ $5 \mathrm{gm}$ )で刺激し, 圧点 の有無で判定した。

(3) 鍼刺激の方法

上肢, 下肢, 体幹の鍼刺激は, 1 寸 3 分, 3 番（直 径 $0.197 \mathrm{~mm}$ ) のステンレス銊を皮内 $10 \mathrm{~mm}$ 刺入し (横刺)，その $1.5 \mathrm{~cm}$ 外方に不関電極を置き鍼通電 刺激 $(2 \mathrm{~Hz}, 10 \sim 40 \mathrm{~V}, 10 \mathrm{~min})$ を行った。電圧 は原則として触或いは圧覚として感ずる閾值電圧 を用いた。ただし，図 7 では銊は皮内 $5 \mathrm{~mm}$ 横刺 し銊通電刺激（2 Hz，10V，5 min）を行った。

\section{III 実験 結 果}

1 ) 融合野の特徵

（a）融合野の面積と形状

A

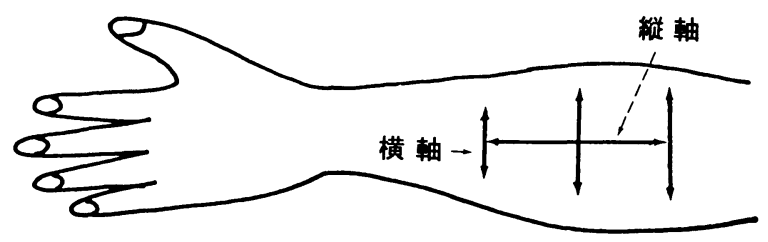

B

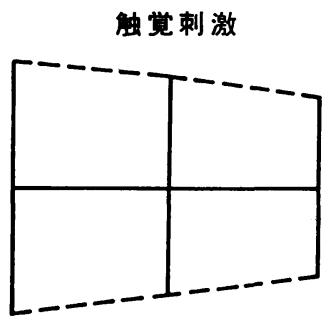

$8.8 \mathrm{~cm}^{2}$
圧賞刺激

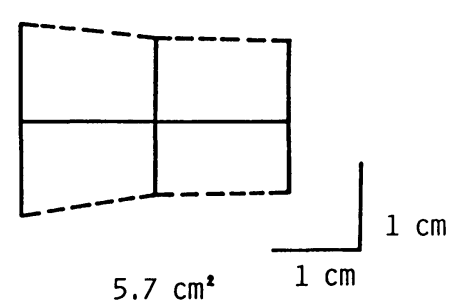

図2 前腕部の二点融合野の製作方法

$\mathrm{A} ：$ 二点融合野の測定部位

$\mathrm{B}, \mathrm{C} ：$ 各刺激による融合野（実線と破線

に囲まれた面積)

数字 $\left(\mathrm{cm}^{2}\right)$ は各融合野の面積を示す。 
融合野について前腕外側の同一部位で触賞刺激 と圧覚刺激で実験した（図 2 A)。触覚刺激では融 合野の面積が大きく $\left(8.8 \mathrm{~cm}^{2}\right.$, 図 $\left.2 \mathrm{~B}\right)$, 圧覚刺激 では小さい $\left(5.7 \mathrm{~cm}^{2}\right.$, 図 $\left.2 \mathrm{C}\right)$ 。このように両者に は明らかに面積の相違が認められた。

融合野の形状は部位により異った形を呈する。 それは正方形，長方形あるいはそれらに近い形で あったり（図 2 B，C参照）, 六角形に近い形であ ったりする(図4 Bの実線)。これらの融合野の面 積と形状は一般に同一被検者では再現性はかなり 良い。しかし，同一被検者の同一部位でも異なる 場合もあつた。

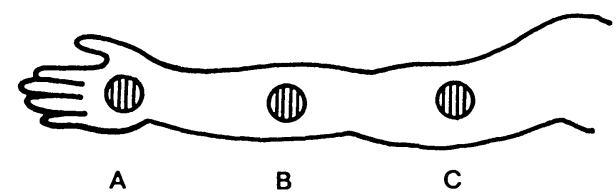

\section{二点融合野}
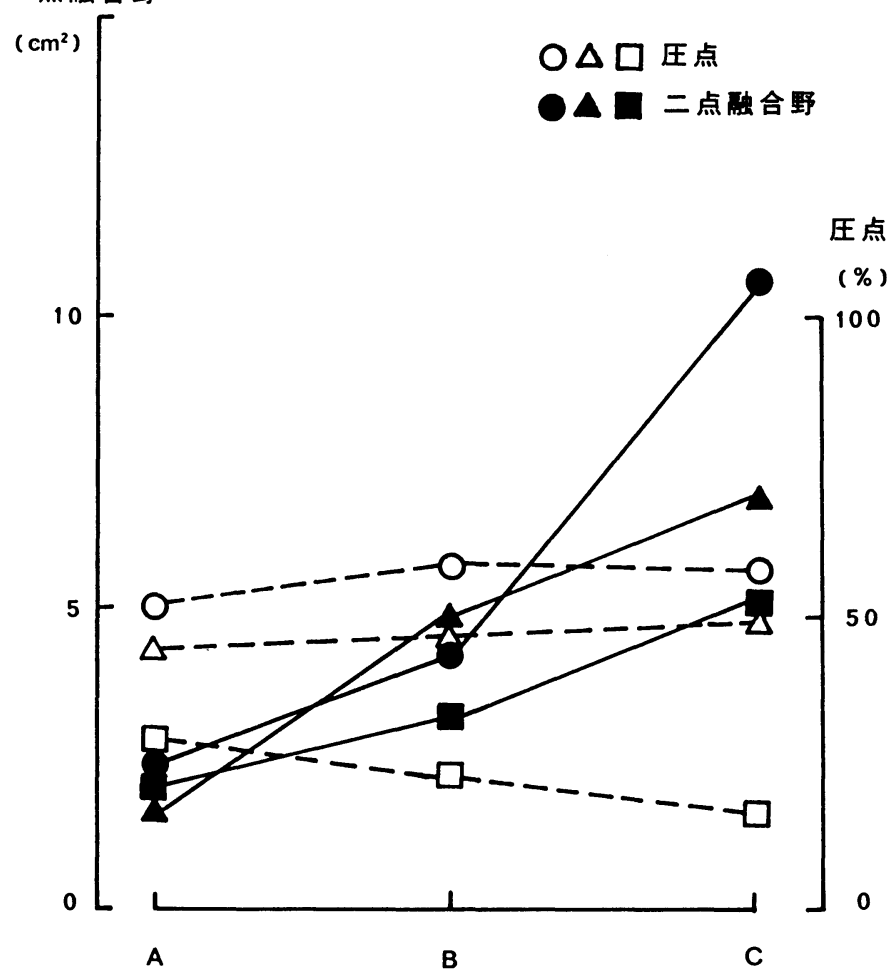

図3 二点融合野の部位と圧点

左縦軸に融合野 $\left(\mathrm{cm}^{2}\right)$, 右縦軸に圧点 $(\%)$ を とり，横軸は測定部位をとった。記号（○，

•)等は同一被験者を示す。 （b）融合野の面積の経時的変化

触覚と圧覚刺激による融合野の面積の経時的変 化を検討した。一般に触覚刺激と圧覚刺激の融合 野は最初の 5 分までは変動し易い。その後は触覚 刺激よりも圧覚刺激の方が経時的変化が少なく, また形状，面積もほぼ一定であり，以下の実験で は主に圧覚刺激で行った。

（c）上肢の融合野の面積の部位差

融合野の面積には部位差が認められ，これにつ いて上肢で検討した。測定部位は手背部 $(\mathrm{A})$, 前 腕外側部 (B)，上腕外側部 ( C )で行った（図 3 挿 入図参照)。図 3 は代表的な 3 例で，実線が上肢の 部位による融合野の面積を表わす。 融合野は上腕部7.0 $10.5 \mathrm{~cm}^{2}$, 前腕 部4.5 $5.0 \mathrm{~cm}^{2}$, 手背部1.5 2.5 $\mathrm{cm}^{2}$ の順に小さくなる。

ところで上述の上肢の融合野の部 位差が何に基因するかを検討するた め, 圧点の密度を測定し融合野の面 積との関係を求めた。困 3 の破線は 各部位の圧点の密度を示すが, 圧点 の密度にはほとんど変化は見られな い。したがって融合野の面積の部位 差を圧点の数から説明することはで きない。

なお，背部では上肢のどの部位よ りも融合野の面積が大きい（最大 20 $\mathrm{cm}^{2}$ )。

2 ）鍼の刺激条件による融合野の拡 大効果

(a) 同側の銊刺激

合谷に閾值下の鍼刺激をしても融 合野の面積にはまったく変化が見ら れない。次に合谷へ銊の閾值刺激を して，抜銊後 1 分， 8 分，15分に融 合野の測定をすると何れも融合野は 拡大するが，そのうちの最大拡大值 について検討した。

触覚刺激と圧覚刺激の融合野の測 定部位は前腕外側部で，鍼刺激は合 谷に行った。図4のAは触覚刺激で 融合野の測定を行った場合，Bは圧 
触覚刺激

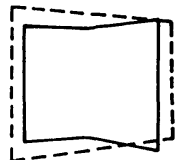

压堂刺激

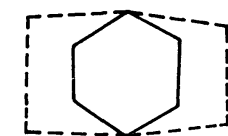

図4鍼刺激による融合野の拡大効果

実線は対照，破線は鍼刺激後の拡大を示す。

I 型

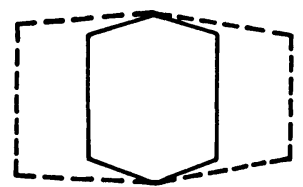

(190\%)

II 型

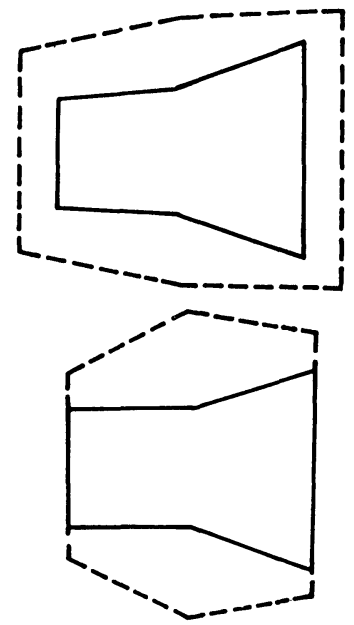

$(180 \%)$

$(188 \%)$

\section{図5銊刺激による融合野の拡大形式}

実線は対照，破線は鍼刺激後の拡大を示す。 数字 $(\%)$ は拡大率

覚刺激で行った場合である。実線は対照を，破線 は銊刺激後の融合野の拡大を表わしている。同側 の合谷への鍼の閾值刺激により前腕外側部の融合 野は, 触覚刺激では $15 \mathrm{~cm}^{2}$ から $20 \mathrm{~cm}^{2}$, 圧覚刺激 では $7 \mathrm{~cm}^{2}$ から $20 \mathrm{~cm}^{2}$ と特に圧覚刺激では著しい 面積の拡大を呈す。

また融合野の形状も変化する。すなわち融合野 の拡大には 3 つの拡大形式がある（図 5 ）。何れも
180 190\%の拡大効果を示すものでも，その拡大 の方向に特徵がみられる。I 型では上肢の縦軸方 向（図 2 A 参照)，すなわち図 5 では左右方向の拡 大効果，II 型は全体的な拡大効果，III型は横軸方 向，この図では上下方向の拡大効果がみられた。 このI 型は上肢に多く見られ，II 型は上肢，体幹 ともに見られ，III型は体幹に多く見られる。この ように被検者により或いは部位により，その拡大 のし方に特徵を有することが実験により確められ た。

（b）同側，反対側，両側の銊刺激

鍼刺激によって反対側の融合野がどうなるかを 検討した。これは鍼炎でよく知られる巨刺法 ${ }^{6}$ ( $($ 病 が右にあれば左を治療し，病が左にあれば右を治 療する。)である。測定部位は前腕外側部で，鍼刺 激は同側合谷，反対側合谷，両側合谷にそれぞれ 圧覚の閾值電圧 $(9 \mathrm{~V})$ で実験を行った（図6 挿 入図参照)。その結果，実線で示されるように同側 合谷の銊刺激では $161 \%$ 拡大, 反対側合谷の鍼刺 激では $149 \%$ の拡大効果が認められた。ところで両 側合谷の同時刺激では実線で示すように $270 \%$ と はなはだしい拡大効果を示し，生理学でいう加重 現象が認められた。

反対側の融合野への影響について，同様の実験 を鍼刺激量を変えて検討してみた。この場合圧覚 の刺激電圧について閾值以下（圧覚閾值電圧の $1 / 2$, すなわち $4.5 \mathrm{~V}$ の電圧)で実験を行った。このとき は非常に弱い触覚か或いは何も感じない電圧であ る。図 6 の破線で示されるように，同側合谷，反 対側合谷の閾值下刺激では何れも拡大効果が認め られなかった。しかしながら両側合谷の同時刺激 では破線で示されるように $158 \%$ の拡大効果が現 れた。これは生理学でいう促通現象である。

以上のように刺激量，すなわち閾値刺激はもち ろんのこと閾值下刺激でも，合谷の両側同時刺激 で融合野の拡大効果の増大が認められた。

\section{IV 経穴と非経穴の鋮刺激による 融合野の拡大効果}

（1）同一デルマトーム上の経穴と非経穴の鍼刺激 銊炎医学では経穴が重要視されているが，同一 デルマトーム上で経穴と非経穴の鍼刺激を検討し 


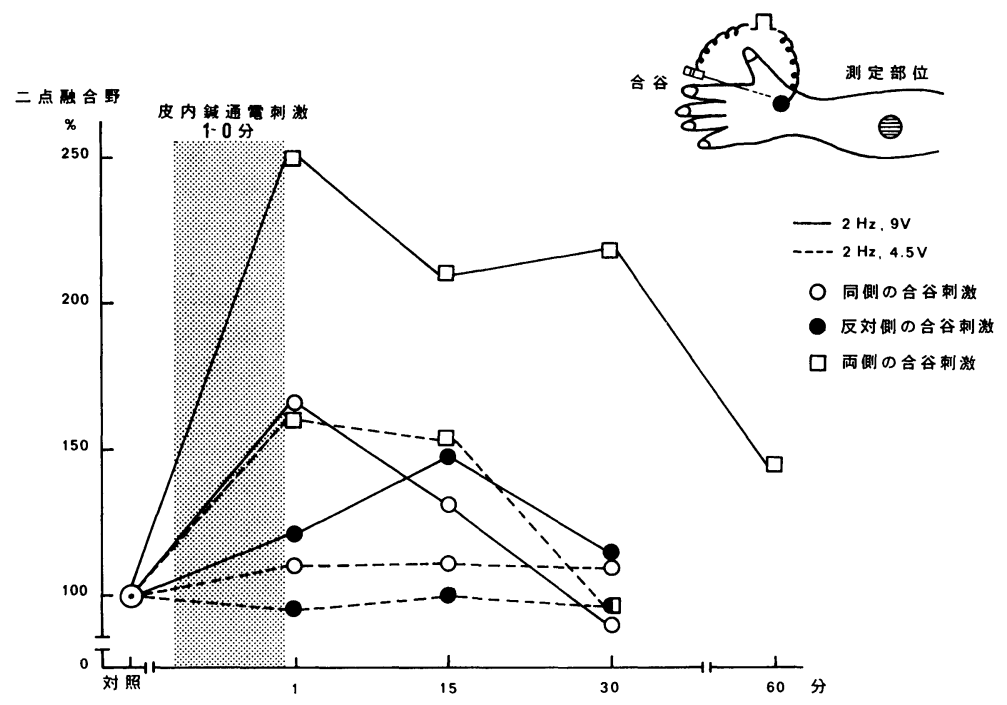

図6同側, 反対側および両側の銊刺激効果

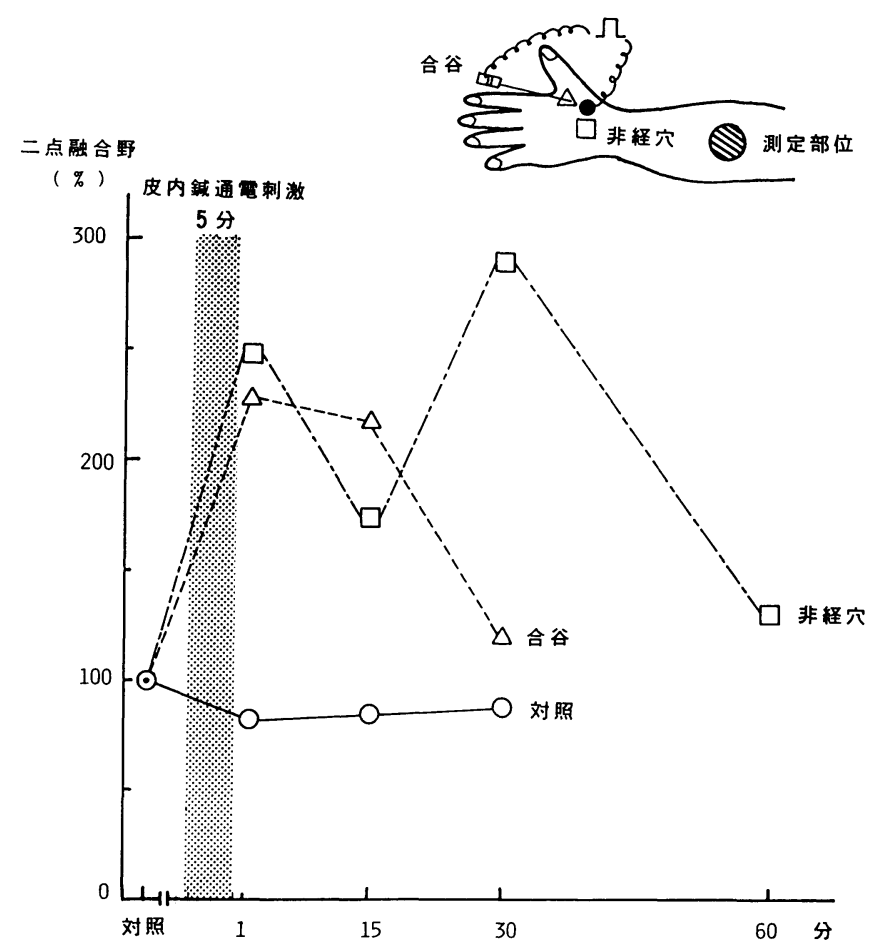

図7同一デルマトーム内の経穴と非経穴の 銊刺激効果 


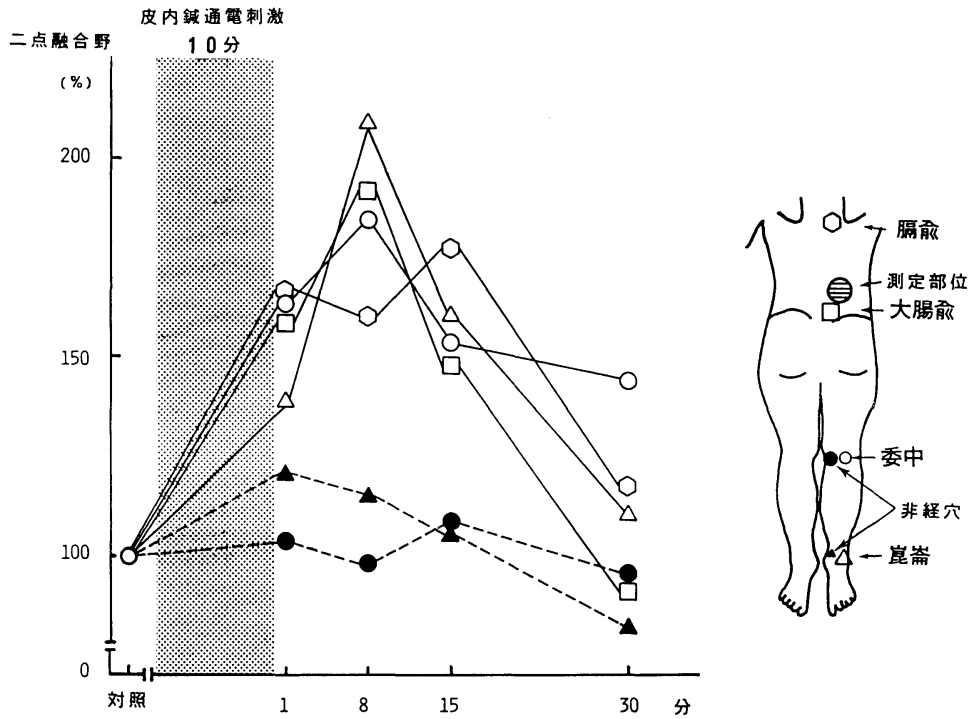

図8同一経絡上の経穴と非経穴の銊刺激効果

た。前腕外側部（デルマトーム $\mathrm{C}_{6}$ ）の融合野につ いて，合谷 $\left(\mathrm{C}_{6}\right)$ と非経穴部（合谷より中枢側で 約 $3 \mathrm{~cm}$ 離れた $\mathrm{C}_{6}$ あるいは $\mathrm{C}_{7}$ の部位)に銊刺激を 行って実験した（図７挿入図参照）。経穴刺激では 対照值に戻った30分まで，非経穴刺激では60分ま で測定した。このように経穴，非経穴への鍼刺激 により何れも $200 \%$ 以上の拡大効果が見られ，非 経穴刺激の方の回復が遅かったが両者間に本質的 な差は見られなかった。以上の所見から，測定部 位と鍼刺激部位が同一かあるいは隣接のデルマト 一ムでは，経穴と非経穴とではほぼ同様の拡大効 果を示した。

(2) 同一経絡上の経穴と非経穴の鍼刺激

同一経絡上で鍼刺激効果を検討するため膀胱経 で実験を行った。これは銊尒臨床で遠隔部の経穴 刺激による遠隔作用がよく知られているが，その 一端について検討してみた。またこれについて遠 隔部の非経穴でも実験してみた。

融合野の測定部位は膀胱経の腎俞付近とし, 鍼 刺激は近位部経穴の大腸俞, 遠隔部経穴の崑崙, 委中，上部の膈俞で行った。また遠隔部非経穴は 崑崙，委中と同一デルマトーム内で経穴より 2 $3 \mathrm{~cm}$ 離れた部位で行った(図 8 插入困参照)。図 8
実線が上述の経穴の銊刺激による融合野の拡大を 示している。この被検者の場合では崑崙 $208 \%$, 委 中 $183 \%$, 大腸俞 $192 \%$, 膈俞 $180 \%$ ，遠隔部の経 穴でも近位の経穴と同等かあるいはそれ以上の拡 大効果が認められた。またこの時の圧の銊通電刺

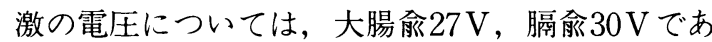

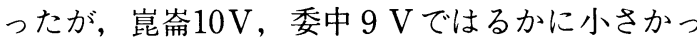
た。このようにどの被検者でも体幹よりも下肢で は低い鍼刺激電圧であった。このことより崑崙,

委中は非常に刺激効果の高い経穴であることが実 験より確められた。一方，破線は非経穴への鍼刺 激の結果を示している。いずれも110～120\%とほ とんど拡大効果が認められなかった。

（3）遠隔デルマトームと同一経絡上の経穴と非経 穴の鍼刺激

銊尒医学で重視する縦の経絡，西洋医学のデル マトームとが直角に交叉する部位について鍼刺激 の効果を検討してみた（図 9 左参照）。

融合野の測定部位はデルマトーム $\mathrm{T}_{10}$ の背部(正 中線の外方）で一定にした。鍼刺激部位は測定部 位から遠隔のデルマトーム $\mathrm{C}_{7}$ の上腕部の非経穴, $\mathrm{C}_{7}$ と膀胱経が交叉するところの経穴として附分で 行った。融合野の測定部と同一デルマトームでは 

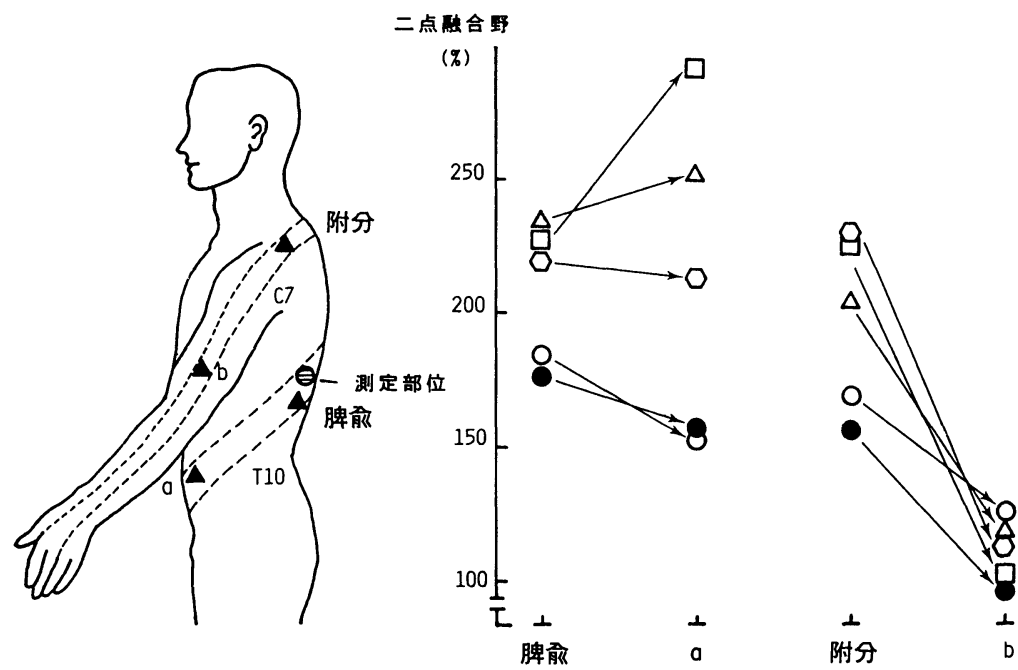

図9膀胱経上の経穴と同一デルマトーム $\left(T_{10}, C_{7}\right)$ 内の非経穴の鍼刺激効果

$\bigcirc, \bigcirc, \triangle, \square, \bigcirc$, は同一被験者を示す。

$\mathrm{T}_{10}$ の腹部の非ツボ, $\mathrm{T}_{10}$ と膀胱経が交叉する経穴 として脾俞で行った。困 9 は五人の被検者のデー 夕を示した。遠隔デルマトーム $\mathrm{C}_{7}$ の非経穴の鍼刺 激( b )ではほとんど拡大効果が認められなかった $(102 \%)$ が，附分の鍼刺激では $160 \%$ で強い拡大を 示した。同一デルマトーム $\mathrm{T}_{10}$ の非経穴 $(\mathrm{a})$ と脾 烝の鐵刺激では，前者が150\%，後者が180\%とい ずれにも拡大効果が認められた。このように同一 デルマトームでは経穴と非経穴の鍼刺激により著 明な拡大効果が得られたが, 遠隔デルマトームの 非経穴では拡大効果はなかった。

\section{$\mathrm{V}$ 考 察}

\section{1. 二点融合距離}

二点融合距離の測定は従来の二点弁別閾值より も容易で測定誤差が少ない。触と圧覚刺激で比較 すると, 圧覚刺激による二点融合距離や融合野の 方が再現性が高い。上肢で融合野の形状は長方形 でほぼ一定で, 触覚刺激よりも圧覚刺激で面積も 小さく安定して変動が少ない。また経時的変化も 比較的少ない。この理由は, 圧覚刺激による感覚 神経のインパルスが常に持続性発射をきたし, 後 述の側方抑制機構を安定に働かせるからである。

\section{2. 融合野の部位差}

融合野の面積は手背, 前腕, 上腕の順に大とな る(図 3 参照)。このような部位差について考察す る。

(a) 感覚点

感覚点としては触，圧点が考えられる。我々が 主として試みた圧覚刺激は遅順応受容系を活動さ せ, 受容器としては Ruffini, Merkel 小体などが 考えられる。そこで融合野の面積を圧点の密度と 閾值から考察してみよう。

(1) 圧点の密度

圧点は手掌には非常に多いが手背，前腕，上 腕では圧点の数はあまり変わらない。

(2) 圧点の閾值

最も鋭敏なのは舌の先端, 口唇，指尖である が，上肢外側では手背，前腕，上腕の閾值はあ まり変わらない?。

これらのことより融合野の面積の部位差を圧点の 数と閾值から説明できない。

（b）末梢感覚神経の受容野

指尖，手掌では触，圧を支配している感覚神経 線維の受容野（感覚単位, 感覚神経支配領域とも いう）は小さくほぼ一定である。しかし振動感覚 


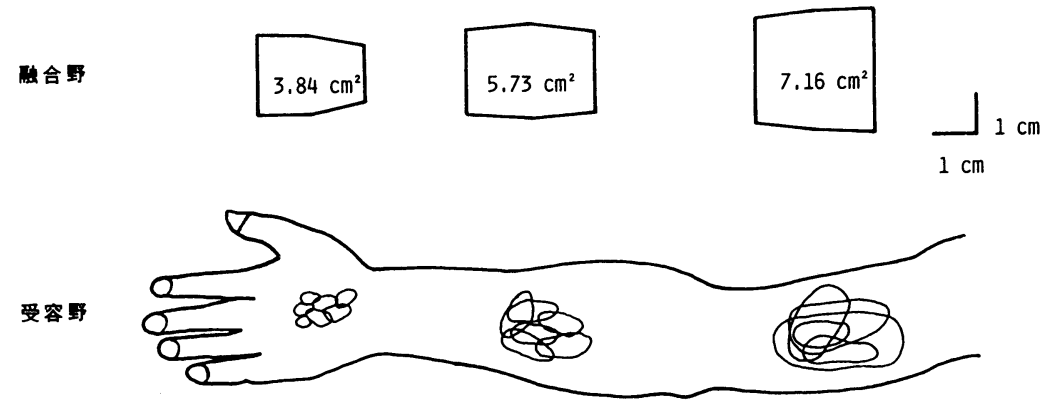

図10 二点融合野の部位差と圧受容野の比較

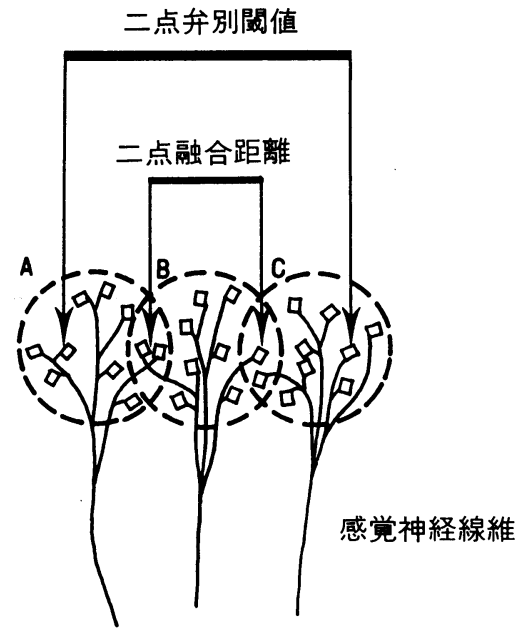

図11 二点融合距離と二点弁別閧値の.末梢神 経機序

$\mathrm{A}, \mathrm{B}, \mathrm{C}$ : 受容野 $\square$ : 受容器

の受容野は手掌では非常に大きいことが知られて いる ${ }^{8)}$ 。

ところで上肢における圧の受容野の大きさは手 背の方が前腕，上腕に比べて必ずしも小さいとは 言之ない。これは皮膚の感覚神経支配の密度(innervation density）の相違に基づくからで, 融合野 の部位差の説明にはならない。

(c) 中枢神経系の受容野

サルの触, 压による受容野の直径は指尖掌側で 最も小さく $(1.5 \mathrm{~mm})$, 手背では $7.5 \mathrm{~mm}$ である。 この值は二点弁別閾值にほぼ等しい量。

このように上肢の受容野を大脸皮質の体性感覚
野ニューロンで検討すると，手背では受容野は小 さく，数も多く，重なり合いもほとんどなく二点 弁別がよい。前腕から上腕部でしらべると受容野 も大きくなり，重なり合いが多くなって二点弁別 が悪くなる (図10参照)。したがって融合野の部位 差は末梢の圧点，感覚神経の受容野の立場から説 明するよりも，中枢神経系を含んだ神経機構を考 慮した方が理解しやすい。この点から二点弁別や 二点融合の感覚は単なる触，圧などの皮膚感覚よ りも高次の感覚を意味するといえよう。

3. 融合野の神経機序

(a) 融合野の末梢機序

二点の圧覚刺激を与えて二点融合感覚をきたす 末梢神経機序としては，原則として一つの圧受容 野内 $(\mathrm{B})$ に二点刺激が存在することである(図11)。 しかし二点の圧覚刺激の一つが隣接の受容野（A またはC）内に存在しても二点弁別は不可能で融 合感覚を生ずる。そこでこの二点弁別の末梢機序 としては，二点刺激の間に少なくとも一個以上の 興奮しない受容野 $(\mathrm{B})$ )の存在が必要であろう（図 11参照)。

（b）融合野の中枢神経機序

二点刺激からの圧インパルスは中枢神経系内に 入ると，ニューロンの連絡方式と刺激条件によっ て次のことが起こる。

(1) インパルスの発散 (divergence) により, 多数のインパルスが脳に達したり（促通),脳の 広い範囲を興奮させる（空間的拡大現象）。

(2) インパルスの収斂 (convergence) により, 脳の局部的興奮を起こす（空間的縮少現象）。 
(3) 介在性抑制ニューロンによる側方抑制 ${ }^{10)} の$ 機構（図12のL I ）が作動して，圧インパルス は脊髄内の中継核 $\left(\mathbf{A}^{\prime}, \mathbf{B}^{\prime}, \mathbf{C}^{\prime}\right)$ ではなはだしい 修飾を受けて体性感覚に伝達される（図12）。す なわちこの側方抑制機構によってA'，C'のイン パルスは中継核で抑制を受けて消失し，圧イン パルスはB'ニューロンの経路のみに存在する。 こうして感覚の正確度や二点弁別などの分離度 がはなはだしく改善される。

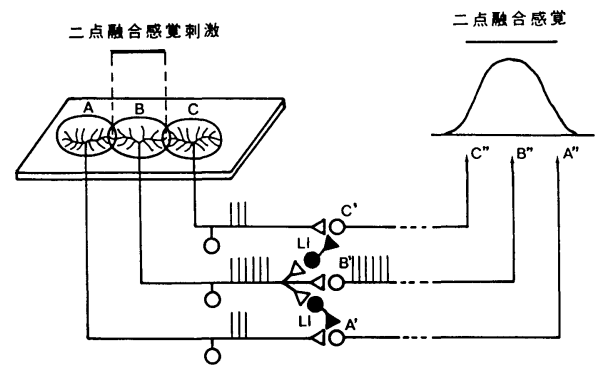

\section{図12 二点融合感覚の中枢神経機序}

$\mathrm{A}, \mathrm{B}, \mathrm{C}$ ：受容野 $\mathrm{A}^{\prime}, \mathrm{B}^{\prime}, \mathrm{C}^{\prime}$ : 中継ニューロン $A^{\prime \prime}, B^{\prime \prime}, C^{\prime \prime}$ : 皮質感覚野 LI：側方抑制ニューロン 业：神経線維のインパルス群
以上の所見は，触覚刺激より圧覚刺激で融合野 が小さくなること，また脳の活動レベルや皮膚か らの求心性インパルス（例之ば鍼刺激）によって 融合野は変わり得ることを意味している。

4. 鍼刺激による融合野の拡大とその神経機序

鍼刺激は痛みの軽減, 各種の疾患の治療に与 るが、これは一つには中枢神経系が関係している からである。皮膚へ鍼刺激をすると皮膚感覚の一 つである融合野の拡大現象が明らかになった。

(a) 拡大の形式, 加重, 促通

拡大現象は前述の空間的縮少機構が消失したり, 空間的拡大 (増幅) 機構の活動によるものと考之 られる。融合野の極大は約 200\% 以上におよび, その形式としては上肢では I 型（図 5 ), 体幹では III型が代表的なものである。また，部位特異性も 見られるがその理由はわからない。これら融合野 の拡大に当って，銊の刺激条件によって加重や促 通の現象が生ずる。また歯の疼痛閾值上昇に対し, 同一デルマトーム（四白）と異ったデルマトーム (合谷)の銊(経皮的神経) の同時刺激では，閾值 は二倍以上も上昇する（空間的加重現象）ことが

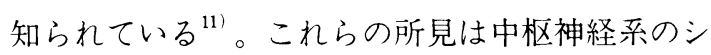

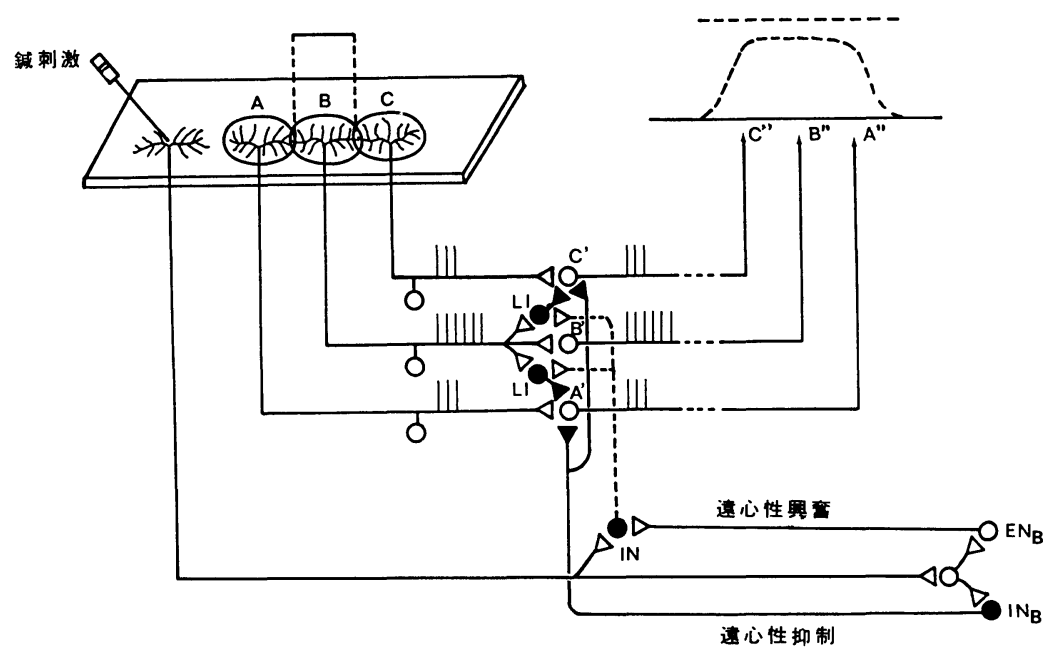

図13 銊刺激による二点融合野の拡大機序

$\mathrm{A}, \mathrm{B}, \mathrm{C}$ : 受容野 $\mathrm{A}^{\prime}, \mathrm{B}^{\prime}, \mathrm{C}^{\prime}$ : 中継ニューロン

$A^{\prime \prime}, B^{\prime \prime}, C^{\prime \prime}$ ：皮質感覚野 LI：側方抑制ニューロン

$\mathrm{EN}_{\mathrm{B}}$ : 脳幹の興奮性ニューロン $\mathrm{IN}_{\mathrm{B}}$ : 脳幹の抑

制性ニューロン IN：抑制性ニューロン

业：神経線維のインパルス群 
ナプスレベルでの生理学的現象の発現で，鍼の作 用機序の一端を示している。

また鍼尒臨床では治療に当って銊の刺激量がよ く問題にされる。しかし実際には正確な定義はな く, 病気の種類, 臨床症状や部位などで臨床家の 経験にゆだねられている。本実験では，融合野の 立場から鍼刺激条件（銊通電の際の電圧と刺激部 位）についてのデー夕を提供した。すなわち刺激 条件の設定の如何によって，銊の治療効果の有無 につながることがこの実験からわかった。

(b) 末梢からの求心性抑制による脱側方抑制

鍼刺激をすると，皮膚の $\mathrm{A} \beta$ 線維 $^{12)}$ の興奮によ って，図13のIN ニューロンが活動すると側方抑 制ニューロン LI の活動が減弱する(脱側方抑制)。 その結果 $\mathrm{A}^{\prime}, \mathrm{C}^{\prime}$ ニューロンのインパルスは消失し ない。したがって脳のA"，B"，C”ニューロンが興 奮し融合野の拡大をきたす。抑制機構が存在する 部位としては脊髄, 脳幹の後索核, 視床中継核, 体性感覚野などである。神経機序としてはIPSPや シナプス前抑制が考えられる ${ }^{13-15)}$ 。

（c）上位中枢からの遠心性抑制

銊刺激による求心性インパルスは体性感覚野に 達するが，その途中たとえば脳幹で遠心性二ュー

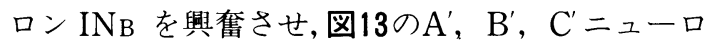
ンの抑制を起こしたり，遠心性ニューロン ENB を 介してINの活動によって側方抑制ニューロン LI の働きをなくしたりする。これらの所見は融合野 の拡大を神経レベルからよく説明できるものであ る。以上の神経機構は秒のオーダーの現象である。 ところが拡大現象は銊刺激後30分にもおよぶ。こ れは求心性インパルスが中脳中心灰白質 ${ }^{16}$ 視床下 部弓状核ニューロン ${ }^{177}$ を興奮させて, 液性の抑制 機構が働くからであろう。

5. 鍼刺激による融合野の拡大と経絡

鍼炎治療では基本となり且つ重要性を持つ経穴 や経絡の立場から，この銊炎による融合野の拡大 効果を考察した。IVで説明したように，融合野の 測定部位と同一デルマトーム上の経穴, 非経穴(図 7 ), また同一経絡上の経穴への鍼刺激（図８）で は融合野の拡大効果はいずれにも認められた。こ れは鍼刺激が春髄分節的に春髄に入ることによっ て融合野の拡大をきたしやすいからである。一方，
融合野の測定部位に対する遠隔デルマトームの非 経穴刺激（図 9 ）では拡大効果が認められなかっ た。これは脊髄分節的な刺激効果が出現しないか らと考えられる。この遠隔デルマトーム上であっ ても，融合野の測定部位と同一経絡上の銊刺激で は拡大効果が認められた。銊尒では治療に当って その選穴方法は種々あるが，ある経絡の疾患はそ の経の穴を使って治療をするというのが基本であ る。つまり言いかえれば，ある経穴への鍼刺激は その経絡に作用を及ぼすということになる。その 観点から図 9 で附分穴への鍼刺激で，その同経絡 上の測定部位に拡大効果が得られる現象は当然と いえる。

経絡では膀胱経で遠隔作用について検討した。 下肢には六本の経絡が走行しており，膀胱経は下 肢後側中央から外側にかけて走行している。この 実験の非経穴では拡大効果が得られなかった。こ のことについて非経穴部位は膝窩部では委中より 内側で，これは経絡でいうと少陰腎経や太㓌脾経 に近い側に属し，これらの経絡は腹部へ連ってい る。また崑崙に対する非経穴についても, やはり その付近は腹部へ連なる経絡の通るところであっ た。鍼炎臨床ではよく使われる同一経絡上での遠 隔療法を裏付ける実験結果である ${ }^{18)}$ 。

\section{VI 結 論}

皮膚への触, 圧覚刺激による二点融合距離を縦, 横軸の両方向で測定し融合野を求めた。上肢と体 幹の融合野について次の結果を得た。

1. 二点融合距離と融合野の特徵

(a) 二点融合距離は二点弁別閾値よりも測定しや すく，また再現性がよい。

(b) 融合野は上肢では長方形，体幹では正方形に 近く，その面積は触覚刺激よりも圧覚刺激で小さ く経時的変動も少ない。

（c）上肢外側では上腕，前腕，手背の順に融合野 の面積は小さくなり部位差が認められる。

2. 鍼刺激条件と融合野

合谷へ銊の閾值刺激をすると同側の上肢の融合 野の面積は $200 \%$ 以上も拡大する。また反対側前 腕部の融合野でも拡大効果が認められた（鍼炎の 巨刺法)。両側の鍼刺激を同時に行うと拡大効果の 
加重が起った。同様の実験を間值下の鍼刺激で行 うと融合野の拡大効果は見られない。しかし両側 の閾值下の同時鍼刺激をすると融合野の拡大効果 が起った(促通)。

\section{3. 経穴と非経穴と融合野}

融合野の測定部位と銊刺激部位が同一または隣 接のデルマトームでは, 経穴と非経穴の鍼刺激は ほぼ同様の拡大効果を示した。膀胱経で銊の遠隔 作用について検討した結果, 遠隔部の経穴刺激で も著しい融合野の拡大が起った。しかしその付近 の非経穴の刺激では拡大は認められなかった。

以上の鍼刺激による融合野の面積の拡大効果は 中枢への伝導系内の側方抑制機構が作動しなくな ったことと, 鍼刺激により脳幹などが興奮し上位 中枢からの神経性，体液性の抑制機構が遠心性に 働くからと考えられる。また鍼尒の基礎をなす経 絡の意義が巨刺法と経穴の遠隔刺激作用で裏付け られた。

本論文の要旨は, 第60回日本生理学会大会 (大阪)お よび第33回全日本銊炎学会学術大会(神戸)にて発表し た。

\section{引用交献}

1) D. Sinclair 著, 市岡正道訳：皮膚感覚, 医歯薬 出版, 東京 (1969),

2）須永隆夫, 柴田昭, 新島旭, 小林庄一：ツボの 鍼刺激および圧刺激の皮膚感覚点に及ぼす影響, 自律神経雑誌 $27(2 \cdot 3) ;$ p.269 271. (1980)

3) 前山文子, 熊本賢三: 鍼刺激と皮膚感覚 (二点 融合感覚に与える影響について), 月刊東洋医学 No.144, 明治東洋医学院出版部, (1982), p.1 6.

4）菊地鐐二：感覚に関する実験, 日本生理学会編 生理学実習書, 南江堂, 東京 (1978)

5）福井尚見, 金子篤子, 大久保ゆみ, 佐々木頼子 : 触圧覚・痛覚に関する二, 三の知見, 東女医 大誌 $47 ;$ p.29～34. (1977)

6）長浜善夫：東洋医学概説，創元社, 大阪 (1977)
7) S. Weinstein, Intensive and extensive aspects of tactile sensitivity as a function of body part, sex, and laterality, in the skin senses ed. by D. R. Kenshalo, Springfield, Ill. C. C. Thomas, (1968), p.195 222.

8）宮岡徹, 間野忠明：七トの触圧覚求心性神経発 射の解析, 臨床脳波 22(12); p.800 809. (1980)

9) Weddell, G. : The multiple innervation of sensory spots in the skin, J. Anat. (London) 75 ; p.441 446. (1941)

10) G. von Békésy. : Sensory Inhibition. Princeton University Press, Princeton, (1967)

11) K. Toda and A. Iriki. : Inhibitory actions produced by local electrical stimulation in the caudal spinal trigeminal nucleus in rat, Brain Research Bulletin, vol. 7;169 174. (1981)

12) Toda, K. : Effects of electroacupuncture on the rat jaw opening reflex elicited by tooth pulp stimulation, Jap. J. Physiol. 28;p.485 497. (1978)

13) K. Kubota, Y. Kidokoro and J. Suzuki. : Postsynaptic inhibitions of trigeminal and lumbar motoneurons from the superficial radial nerve in the cat, Jap. J. Physiol. 18;p.198 215. (1968)

14）錦織綾彦, 川本正純, 安雲和四郎, 辻本太郎, 山口雄三：ハリ通電刺激に上る皮虐抑制, 自律 神経雑誌 $27(2 \cdot 3) ;$ p.274 275. (1980)

15）戸田一雄：針鎮痛の神経生理学的基礎 紫燿(東 京都歯科医師会雑誌) 31(5); p.7 16. (1983)

16）武重千冬：針鎮痛の機序, 神経研究の進歩 26 (5); p.948 965. (1982)

17) Hamba, M. and K. Toda. : Acupuncture effects on the neuronal activity of the arcuatemedian eminence cells of the rat hypothalamus, 日本生理学会誌 45(8.9); p.493. (1983)

18）山下詢：鍼炎治療学(正経と奇経の運用), 医歯 薬出版, 東京 (1976)

（干920-02 金沢市南新保町ル53番地 東洋医学臨床研究所） 


\title{
The Two-point Fused Sensory Area of the Skin and the Effect of Acupuncture Stimulation
}

\author{
Fumiko Maeyama, Yoshihiko Iwase \\ Department of Physiology, Meiji College of Acupuncture \\ Kenzo Kumamoto \\ Department of Anatomy, Meiji College of Acupuncture
}

The two-point fused sensory area (fused area) was calculated from two-point fused distance. The fused area was enlarged by acupuncture stimulation. This enlargement of the fused area by acupuncture was explained on the point of the central nervous mechanisms.

Applying the two points of touch and pressure stimuli to the skin, the threshold separation required for the two stimuli to be noticed as one rather than two points was determined. On the same region of the body, three longitudinally combined points and one transversally combined point were measured and the area which was surrounded by them was calculated.

The fused area was more enlarged through the touch stimuli than through the pressure ones. On the upper limbs, the shape of the fused area was like an oblong and the area was smaller at the peripheral part than the central part. Acupuncture stimulation enlarged the fused area. This was concerned that the lateral inhibition could not be worked in the tract by impulses which were generated by acupuncture. 